\title{
MULTITASKING ELEMEN BANGUNAN
}

\author{
Franky Liauw ${ }^{1}$ \\ ${ }^{1}$ Program Studi S1 Arsitektur, Jurusan Arsitektur dan Perencanaan, Fakultas Teknik, Universitas Tarumanagara \\ Email:frankyl@ft.untar.ac.id
}

\begin{abstract}
ABSTRAK
Elemen karya arsitektur berupa bangunan biasanya diuraikan menurut peran masing-masing. Kamus sering menjadi acuan untuk memahami pengertian setiap kata, namun perlu diwaspadai karena kamus hanya memberi pengertian dasar, dan sering juga menjadi pembatas pemikiran yang kadang menghambat pengembangan lebih jauh. Sebagai contoh, dalam kamus atap didefinisikan sebagai penutup bangunan bagian atas, padahal sudah sejak lama atap digunakan juga sebagai roof garden. Di tengah banyaknya masalah dalam lingkungan, seperti krisis energi, kekurangan sumber daya tak terbarukan, pemanasan global, berbagai jenis polusi, dan lainnya, pemberdayaan elemen-elemen bangunan untuk fungsi-fungsi lain di luar peran dasarnya, akan memberi nilai tambah, menghemat biaya dan luasan ruang, dan berbagai manfaat lainnya. Tulisan ini menggunakan metode kualitatif deskriptif, berupa perbandingan definisi dalam kamus dengan perkembangan dalam praktek arsitektur, serta analisis berbagai kemungkinan dan peluang pengembangan peran setiap eleman bangunan. Manfaat pemberdayaan elemen bangunan seperti ini dapat dikatakan sebagai rancangan yang ramah lingkungan karena sesuai dengan prinsip pengembangan berkelanjutan. Sebagai contoh, atap memberi perlindungan bagi isi bangunan terhadap pengaruh luar yang tidak nyaman, namun paparan matahari dengan panas yang berlebihan dapat dikonversi menjadi energi. Atap bangunan juga dapat menampung kegiatan manusia. Kegiatan berolahraga yagn banyak mengeluarkan energi, sebenarnya dapat dikonversikan menjadi energi listrik melalui pemberdayaan berbagai elemen bangunan. Upaya menambahkan sebanyak mungkin fungsi lain pada setiap elemen bangunan dalam proses perancangan arsitektur mungkin sebaiknya diajarkan sejak awal di perkuliahan pendidikan arsitektur sehingga akan menjadi kebiasaan yang melekat pada setiap perancang. Definisi dalam kamus perlu dilihat dengan lebih kritis, tidak langsung dijadikan sebagai acuan yang kaku.
\end{abstract}

Kata kunci: elemen arsitektur; pemberdayaan

\begin{abstract}
Elements of architectural works in the form of buildings are usually described according to their respective roles. The dictionary is often a reference to understanding the meaning of each word, but it needs to be aware because the dictionary only gives a basic understanding, and often also becomes a barrier of thought that sometimes hinders further development. For example, in the dictionary the roof is defined as the top of the building cover, even though it has long been used as a roof garden. In the midst of many problems in the environment, such as the energy crisis, lack of non-renewable resources, global warming, various types of pollution, etc., empowering building elements for other functions outside their basic role, will provide added value, save costs and space, and various other benefits. This paper uses descriptive qualitative methods, in the form of a comparison of definitions in the dictionary with developments in architectural practice, as well as an analysis of the various possibilities and opportunities for the development of the role of each building element. The benefits of empowering building elements like this can be said to be environmentally friendly designs because they are in accordance with the principles of sustainable development. For example, the roof provides protection for the contents of buildings against uncomfortable external influences, but exposure to the sun with excessive heat can be converted to energy. The roof of the building can also accommodate human activities. Sports activities that release a lot of energy, can actually be converted into electrical energy through the empowerment of various building elements. Efforts to add as many other functions as possible to each building element in the architectural design process might be best taught from the beginning in architecture education courses so that it will become a habit inherent in every designer. Definitions in a dictionary need to be viewed more critically, not directly made as a rigid reference.
\end{abstract}

Keywords: architectural elements; empowerment 


\section{PENDAHULUAN}

\section{Latar Belakang}

Banyak orang merasa takut atas perubahan yang terjadi dengan sangat cepat, dan ketidakpastian menghadapi masa depan (Land, 2018:20). Perkembangan teknologi berlangsung dengan sangat cepat, melahirkan sebutan revolusi industri 4.0, serta generasi millennial yang fasih menggunakan teknologi digital. Perkembangan pesat di bidang internet membuat semua informasi dan peristiwa di dunia dapat diakses oleh semua pengguna internet hampir dalam saat yang bersamaan. Informasi yang tersedia berlimpah dalam internet dapat sangat berguna, namun di sisi lain, dapat pula menyesatkan. Land cenderung memuji perkembangan teknologi dengan mengatakan bahwa perkembangan teknologi di abad 20 lah yang menciptakan keselamatan dan keamanan, kualitas hidup dan kesehatan yang semakin baik, dan segala sesuatu yang membuat kehidupan kita semakin berharga hingga saat ini. Perkembangan teknologi tak dapat dicegah atau dihambat, tergantung kita untuk memilih mana yang tepat dan bermanfaat. Sejak revolusi industri pertama, penemuan teknologi merupakan karya cemerlang manusia, tapi arah pemanfaatannya tergantung kita.

Sampai saat ini kamus sering masih menjadi andalan bagi kebanyakan orang untuk mengetahui definisi atau pengertian tentang suatu kata, istilah, atau sebutan lainnya. Arti kata kamus menurut kbbi.web.id adalah "buku acuan yang memuat kata dan ungkapan berikut keterangan tentang makna, pemakaian, atau terjemahannya”. Melalui internet, dengan sangat mudah dapat diakses kamus online berbagai bahasa di dunia, bahkan berbagai bahasa daerah. Berlawanan dengan perkembangan teknologi digital dan internet yang berkembang sangat cepat, definisi dalam kamus online sering kadaluarsa, atau tidak sesuai lagi dengan perkembangan yang terjadi. Kamus terkesan kurang cepat memutakhirkan diri. Sebagai acuan "yang dipercaya" bagi kebanyakan orang dalam mencari definisi, kekurangtepatan arti dapat berdampak buruk. Sebagai sekedar contoh, akupunktur diartikan sebagai "pengobatan atau pemeriksaan orang sakit dengan tusuk jarum (cara pengobatan Cina) dalam kbbi.kemdikbud.go.id, sementara dalam bidang tusuk jarum sudah berkembang cosmetic acupuncture.

Saat ini, dan di masa depan digitalisasi dapat dipastikan akan terus berkembang, dan diharapkan dapat turut membantu tercapainya sustainable development goalnya United Nations. Sudah banyak bukti peran digitalisasi dalam membantu mengurangi kelaparan dan kemiskinan, memerangi perubahan iklim dan perusakan sumber daya alam serta membantu tercapainya kesamaan gender dan mempromosikan kesehatan. Secara sistem, teknologi digital mungkin memang besar manfaatnya, namun informasi di dalam internet sering mengandung hal sebaliknya. Pernyataan bahwa digitalisasi menunjang sustainable development goal mungkin perlu didukung juga dengan kandungan isi di dalam internet yang juga sejalan.

Banyak inovasi sudah dilakukan dalam bidang arsitektur, dengan tujuan ikut menunjang gerakan sustainable developement. Berbagai cara merancang, yang arahnya agar ramah lingkungan sudah juga dihasilkan, misalnya arsitektur hijau, arsitektur eko, arsitektur hemat energi, arsitektur cerdas, dan sebagainya. Inovasi dalam praktik berarsitektur, yang memuat sifat kebaruan, ternyata tidak, atau belum, berimbas kepada perubahan definisi istilah-istilah arsitektur yang 
termuat dalam kamus-kamus yang beredar. Di lain sisi, kamus sering masih menjadi acuan baku untuk memahami dunia arsitektur.

Sebagai contoh, kbbi.kemendikbud.go.id mendefinisikan atap sebagai "penutup rumah (bangunan) sebelah atas; benda yang dipakai untuk menutup atas rumah" (https://kbbi.kemdikbud.go.id/entri/atap). Dinding diartikan sebagai "penutup sisi samping (penyekat) ruang, rumah, bilik, dan sebagainya (dibuat) dari papan, anyaman bambu, tembok, dan sebagainya" (https://kbbi.kemdikbud.go.id/entri/dinding). Lantai adalah "bagian bawah (alas, dasar) suatu ruangan atau bangunan (terbuat dari papan, semen, ubin, dan sebagainya)" (https://kbbi.kemdikbud.go.id/entri/lantai). Banyak contoh lainnya.

Definisi istilah-istilah arsitektur dalam kamus tersebut, walaupun kamus umum, terasa dan terlihat ketinggalan jaman, kurang cepat mengadopsi dan menyerap perkembangan yang terjadi dalam setiap bidang ilmu dan kehidupan. Tulisan ini sendiri akan mencoba mengeksplorasi pemanfaatan atau pemberdayaan setiap elemen bangunan, sehingga lebih berdaya guna, bukan sekedar memenuhi fungsi-fungsi dasarnya saja seperti yang didefinisikan dalam kamus.

\section{Rumusan Masalah}

Definisi dalam kamus sering ketinggalan dibanding perkembangan di dunia nyata. Sustainable development goal membutuhkan inovasi terus menerus, yang kadang mengakibatkan perubahan dan perkembangan di semua bidang terjadi secara cepat. Pemberdayaan elemen bangunan agar menjadi rancangan yang ramah lingkungan akan tidak sesuai dengan definisi dari setiap elemen yang ada dalam kamus, yang biasanya digunakan sebagai acuan ketika merancang.

\section{METODE PENELITIAN}

Tulisan ini dibuat dengan menggunakan metode kualitatif deskriptif. Kamus-kamus online dijadikan sebagai acuan dan pembanding. Literatur-literatur tentang elemen-elemen bangunan ditelusuri untuk mendapatkan gambaran perkembangan yang terjadi dalam dunia praktek, maupun penelitian. Sebagai contoh, Yudina (2015) memberikan banyak contoh tentang elemen ruangan yang sekaligus menjadi furniture, dan sebaliknya. Lalu dilanjutkan dengan melakukan analisis kreatif untuk menemukan ide inovatif alternatif tentang prinsip perancangan arsitektur yang ramah lingkungan.

\section{HASIL DAN PEMBAHASAN}

\section{Definisi yang membatasi peran elemen bangunan}

Dalam bidang arsitektur, dikenal cara aktif dan pasif, untuk menghasilkan rancangan bangunan yang ramah lingkungan. Untuk memenuhi standar perancangan pasif, Corner menganjurkan mengisolasi keseluruhan struktur lantai dan pondasi yang berhubungan dengan tanah, dalam rangka mencegah pengurangan panas dalam ruangan, terutama di daerah beriklim ekstrem keras (Corner, 2018:19).

Tujuan utama perancangan bangunan adalah menciptakan area permukaan yang dapat dimanfaatkan oleh pengguna untuk berkegiatan. Umumnya pemikiran pertama untuk 
menampung kegiatan pengguna adalah berupa lantai, bidang horisontal tempat pengguna berpijak, duduk atau posisi lain ketika melakukan aktivitasnya (Gobin, 2019:55).

Baik kamus, Corner, maupun Gobin, dan mungkin juga banyak pihak lainnya, cenderung membatasi definisi dan uraian tentang elemen bangunan, hanya pada fungsi dasarnya saja. Kamus menyatakan lantai sebagai bagian bawah bangunan atau ruangan, sementara Corner menguraikan tentang perlakuan terhadap lantai dalam rangka mengurangi panas ruangan yang merembes ke bawah melalui lantai, dan Gobin membicarakan tentang lantai sebagai tempat berkegiatan. Tidak ada yang mencoba melihat dari sudut pandang lain. Semua elemen lainnya pun diperlakukan sama.

\section{Tuntutan efisiensi agar berkelanjutan}

Salah satu prinsip ramah lingkungan adalah efisiensi, dalam segala hal. Dalam bidang arsitektur, efisiensi perlu diterapkan dalam setiap tahapan, mulai dari tahap perancangan, tahap pembangunan atau pengkonstruksian, tahap pengoperasian dan perawatan, serta tahap akhir masa pakai (demolition). Dalam konsep pengembangan berkelanjutan (sustainable development), dikenal prinsip 3R. Pertama adalah Reduce, yang berarti mengurangi atau menghemat penggunaan sumber daya hanya seperlunya saja. Kedua adalah Reuse, yaitu sedapat mungkin menggunakan kembali sumber daya yang telah habis masa pakainya. Ketiga adalah Recycle, yaitu mendaur ulang bahan yang telah habis masa pakainya, sehingga dapat digunakan untuk hal lainnya. Bila dulu setelah habis masa pakainya, bangunan dihancurkan dengan dinamit (demolition), kini diubah menjadi dismantling. Komponen bangunan dipreteli, hingga tetap utuh, dan dapat digunakan kembali dengan nilai guna yang tetap tinggi.

Cara berefisiensi tentu tidak berhenti hanya pada prinsip 3R saja, pasti masih terbuka peluang untuk menemukan cara lain, yang mungkin bahkan lebih tepat, paling tidak untuk kasus-kasus tertentu. Yang penting efisiensi dapat tercapai.

\section{Pemberdayaan elemen bangunan untuk fungsi lain}

Upaya membuat bangunan menjadi ramah lingkungan terus dicari dan dioptimalkan. Walaupun sudah banyak solusi yang ditawarkan dan dijalankan, tidak ada salahnya mengusulkan ide baru, atau mengembangkan ide yang belum populer. Hal ini akan menambah solusi ramah lingkungan yang lebih beragam, sehingga terbuka pilihan yang tepat untuk kondisi tertentu.

Setiap elemen bangunan, di samping memenuhi fungsi atau perannya dalam sebuah bangunan, sebenarnya dapat dimanfaatkan lebih dengan menggunakannya untuk fungsi lainnya. Sebagai contoh, atap yang dasarnya memiliki fungsi sebagai penutup bagian atas bangunan, seperti yang didefinisikan dalam kamus, sebenarnya dapat digunakan juga untuk berkegiatan, misalnya sebagai roof garden, yang sudah sejak lama dipraktikkan.

Posisi atap di bagian atas bangunan, terekspos terhadap panas matahari secara maksimal, juga dapat ditutup dengan bahan solar panel, sehingga di samping melindungi bangunan, atau juga menghasilkan energi listrik, bahkan dengan memanfaatkan sumber terbarukan berupa panas sinar 
matahari, yang berlimpah di daerah tropis seperti Jakarta dan Indonesia. Pemanfaatan atap untuk aspek-aspek lainnya masih terbuka luas, demikian pula dengan semua elemen bangunan lainnya. Kolom di tengah ruangan dapat menghalangi pandangan, mengurangi kesan luas ruangan, mengganggu pergerakan, namun dapat juga bermanfaat sebagai pembatas ruangan, pembagi kelompok kegiatan, sebagai fokus perhatian di dalam ruangan, dan sebagainya. Yang jelas, jangan membiarkan kolom hanya berfungsi sebagai struktur penyangga elemen bangunan lainnya.

Pemberdayaan setiap elemen bangunan dengan memberi fungsi tambahan, akan bersifat personal, sesuai dengan kebutuhan tiap pengguna, yang seharusnya unik. Hal ini berkemungkinan terlihat tidak sesuai dengan prinsip efisiensi yang mengarah pada pabrikasi, produk massal yang lebih murah, atau penyeragaman bentuk menjadi sederhana dan lebih hemat. Mungkin pandangan ini ada benarnya, namun manusia juga membutuhkan pengekspresian diri, keunikan, cita rasa estetis, keindahan, kearifan lokal. Pemberdayaan elemen bangunan, selain memenuhi prinsip efisiensi, juga dapat memenuhi kebutuhan akan keunikan dan keberagaman. Tidak terjebak kepada gaya universal, serba terstandardisasi, dan serba seragam, yang membosankan dan mengancam keberlangsungan seni dan budaya yang khas setempat.

Sebagai contoh, Gambar 1 memperlihatkan rancangan dinding, lantai dan plafon yang menyatu tanpa batas yang jelas, bahkan dapat berfungsi sebagai furniture (Yudina, 2015: 10). Semakin banyak fungsi yang dapat ditambahkan pada sebuah elemen bangunan, akan meningkatkan keberdayaan elemen tersebut, dengan kata lain, rancangan menjadi semakin efisien, atau semakin ramah lingkungan.

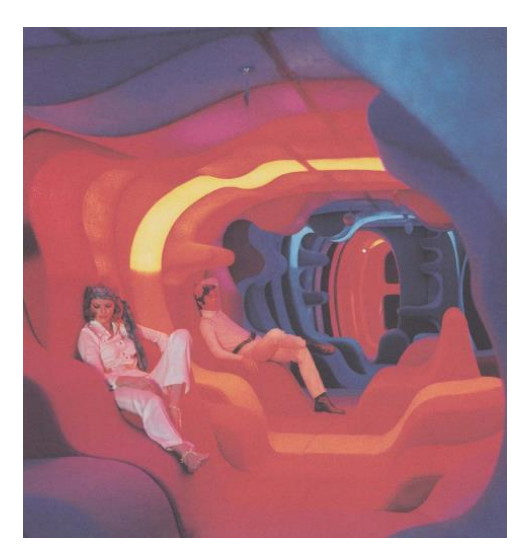

Gambar 1. Dinding sekaligus furniture

\section{Elemen bangunan dan ruang yang multifungsi}

Sejak lama rancangan arsitektur menghasilkan pengelompokan kegiatan-kegiatan, yang kemudian disusun menjadi program ruang. Umumnya ruang-ruang ini diberi nama spesifik sesuai dengan masing-masing kegiatan yang ditampung di dalamnya. Misalnya ruang tidur, khusus untuk tidur, walaupun kadang digunakan juga untuk kegiatan membaca (sebelum tidur), atau untuk bekerja. Kamar mandi untuk mandi dan buang air, dan seterusnya. 
Sebenarnya ada kegiatan-kegiatan yang dapat dilakukan bersamaan, misalnya sambil makan kita dapat juga melihat pemandangan atau menonton acara televisi, tapi banyak juga kegiatan yang tidak dapat dilakukan secara bersamaan. Misalnya ketika tidur, tentu kita tidak dapat sambil makan, ketika mandi kita juga tidak dapat sambil memasak (contoh yang agak ekstrem), atau contoh lainnya. Kondisi ini dapat dimanfaatkan untuk membuat rancangan yang fleksibel. Sebagai contoh, ruang keluarga dapat juga digunakan sebagai ruang tidur, atau sebagai ruang kerja, atau kegiatan lainnya. Fleksibilitas ini tentu perlu diikuti juga dengan fleksibilitas perabotan, yang dapat berubah bentuk. Prinsip rancangan fungsi ruangan dan perabotan yang fleksibel ini akan mengurangi kebutuhan jumlah kamar dalam sebuah rumah, atau bangunan lainnya.

Sebuah ruangan yang dapat menampung beberapa kegiatan, yang berlangsung baik secara bersamaan, maupun secara bergilir, tentu akan mengurangi luas bangunan yang dibutuhkan, tanpa mengurangi ragam kegiatan yang seharusnya ditampung. Kuncinya adalah pengaturan jadwal masing-masing kegiatan yang dibuat tidak overlap. Semakin banyak jenis kegiatan yang dapat ditampung dalam sebuah ruang yang sama, berarti akan semakin meningkatkan efisiensi perancangan. Artinya semakin ramah lingkungan, tanpa mengorbankan tingkat kenyamanan penghuninya. Kala menerima tamu, tentu kita tidak sedang tidur, dan kala tidur kita juga tidak sedang bekerja. Dengan demikian, kegiatan menerima tamu, tidur, dan bekerja, sebenarnya dapat ditempatkan dalam sebuah ruangan yang sama. Tentu saja dibutuhkan rancangan furnitur yang dapat berubah bentuk, sesuai dengan saat masing-masing kegiatan tersebut berlangsung.

Penggabungan beberapa kegiatan dalam sebuah ruangan tentu dapat dicoba-coba dengan berbagai kemungkinan. Yang perlu diperhatikan adalah jadwal yang tidak bentrok antara kegiatan-kegiatan tersebut, serta bentuk furnitur yang dapat dibuat fleksibel memenuhi semua kegiatan tersebut. Hampir semua elemen bangunan sebenarnya dapat diberikan fungsi tambahan, terutama mengingat teknologi bangunan dan material bangunan kini sudah sangat berkembang. Banyak contoh yang sudah dikembangkan. Berikut ini sekedar beberapa contoh yang sudah diterapkan di banyak tempat.

Elemen dinding sebagai pelindung dari intervensi lingkungan terhadap isi bangunan, dapat diberdayakan sebagai penarik perhatian (eye catching), untuk meningkatkan nilai estetik bangunan. Pada bangunan sekolah, material bangunan yang indah dan sedap dipandang dapat meningkatkan suasana menyenangkan dan nyaman sebagai lingkungan belajar (Architect, 2016:2). Konsep form follow function yang dulu pernah sangat dianut oleh para arsitek, kini kelihatannya sudah mulai perlu ditambahkan dengan nilai-nilai lainnya. Fungsi harus tetap terpenuhi, tapi ada manfaat lain yang harus ditambahkan. Setiap elemen bangunan harus diberdayakan.

Pada bangunan Library of Birmingham, United Kingdom, sebagai contoh, Mecanoo sebagai arsiteknya, menambahkan fungsi lain bagi kantilever yang menaungi entrance perpustakaan, yaitu sebagai balkon megah yang menampung kegiatan-kegiatan pertunjukan terbuka 
(Architecture + design, 2016:62). Mecanoo mengubah tipologi kantilever yang selama ini hanya dikenal sebagai penanda pintu masuk sebuah bangunan, menjadi memiliki fungsi tambahan.

Brownell menguraikan bahwa perkembangan teknologi membuat beton dapat menjadi pembangkit dan penyimpan energi, bukan hanya sebagai bahan struktur yang membuat bangunan kuat berdiri. Para peneliti di ETH Zurich telah mengembangkan bahan beton ringan dan adaptif, yang memungkinkan pengaturan thermal, fungsi insulasi, kedap air, dan pembangkit energi, pada bahan beton super tipis yang dilapisi bahan photovoltaic berbentuk film tipis (Brownell, 2018:22). Beton pada semua elemen bangunan, atap, dinding, atau bagian lain bangunan yang menggunakan beton, kini dapat dimanfaatkan lebih.

Bangunan sejak lama dirancang sebagai dalam kondisi statis. Kinetic architecture diharapkan dapat memberikan efek yang berbeda, bahkan menginspirasi berbagai pihak, terutama pengguna. Unsur gerakan dalam rancangan arsitektur dimaksudkan untuk menyesuaikan kebutuhan pengguan di dalam bangunan, juga untuk beradaptasi dengan kondisi luar bangunan (Razaz, 2010:341).

Pembatas ruang berupa dinding statis, fix, tetap, biasanya menampung kegiatan yang memang bersifat tetap, tidak berubah-ubah. Untuk menampung kegiatan yang dapat berubah-ubah, baik bentuk maupun ukuran, atau untuk kegiatan-kegiatan yang berbeda-beda, dinding yang bersifat fleksibel, dapat digeser, atau berubah bentuk dan posisi, akan membentuk ruangan yang dapat disesuaikan dengan kebutuhan ruang yang lebih efektif (Sullivan, 2015:31).

Berbagai kemungkinan penambahan fungsi pada setiap elemen bangunan seperti di atas, tentu membutuhkan analisis lebih lanjut dari berbagai sisi. Faktor ekonomi biasanya menjadi pertimbangan penting dalam menggabungkan elemen bangunan dengan fungsi lainnya. Analisis ini sebaiknya dilakukan secara terpadu, tidak hanya dari sisi ekonomi saja, tapi juga aspek manfaatnya, misalnya dari segi efisiensi ruangan, menghemat luasan ruangan, kepraktisan dalam perawatan berbagai peralatan dan elemen bangunan, dan semua aspek yang terkait.

\section{Fungsi ruang sebagai penentu pemberdayaan elemen bangunan}

Semakin lama jenis kegiatan dan fungsi bangunan semakin beragam. Jenis dan bentuk kegiatan, serta fungsi bangunan, sering digunakan sebagai penentu perancangan semua elemen bangunan. Salah satu fungsi atau kegiatan yang sering "membuang" energi manusia secara sia-sia, adalah kegiatan olah raga. Fitness center umumnya menyediakan berbagai fasilitas atau alat untuk berolah raga di dalam ruangan. Contoh alat yang digunakan, misalnya: sepeda statik, treadmill, berbagai angkat beban berupa besi, dan sebagainya. Tenaga manusia digunakan menggunakan berbagai alat tersebut. Sebenarnya tenaga manusia yang melakukan olah raga dapat dikonversikan menjadi energi listrik dan "disimpan" untuk kemudian digunakan bila diperlukan.

Berbagai elemen bangunan, seperti dinding, lantai, langit-langit, ataupun berbagai elemen lainnya, dapat dirancang untuk menggantikan berbagai alat fitness. Alat fitness berupa beban yang ditarik, dapat dikonversikan menjadi elemen vertikal yang dapat berfungsi sebagai dinding 
pembatas ruangan, dan di dalam dinding tersebut "ditanamkan" alat konversi energi kinetik menjadi energi listrik. Penyesuaian bentuk dan ukuran elemen bangunan menjadi berbagai alat fitness memang membutuhkan rancangan khusus, namun hal ini sangat memungkinkan.

\section{KESIMPULAN DAN SARAN}

Kamus, yang memuat definisi kata-kata, cenderung lamban dalam mengikuti perkembangan di dunia nyata. Untuk itu definisi dalam kamus sebaiknya tidak diikuti begitu saja. Begitu pula dengan uraian-uraian, bahkan pernyataan-pernyataan para ahli dalam berbagai literatur, jangan justru menghambat peluang munculnya ide baru, misalnya dalam hal perancangan ramah lingkungan. Pemberdayaan setiap elemen bangunan, dengan menambahkan fungsi atau fungsifungsi lain kepada sebuah elemen bangunan, di samping peran dasarnya, merupakan langkah yang sesuai dengan prinsip pembangunan berkelanjutan dalam hal efisiensi. Dengan demikian dapat dikatakan sebagai prinsip rancangan yang ramah lingkungan. Penggabungan beberapa kegiatan, yang dilaksanakan secara bergiliran di dalam sebuah ruangan, akan menghemat luasan bangunan, tanpa mengurangi tingkat kenyamanan penghuni. Maka, langkah ini pun dapat dikatakan sebagai rancangan yang ramah lingkungan. Kegiatan olah raga, merupakan kegiatan pengerahan energi untuk memperoleh kesehatan. Namun tenaga atau energi yang dikeluarkan, sebenarnya merupakan "pemborosan" energi yang terbuang sia-sia. Energi manusia yang melakukan berbagai olah raga, dapat dimanfaatkan menjadi energi listrik dengan menggunakan alat konversi energi, yang dirancang sekaligus menjadi elemen bangunan.

\section{REFERENSI}

Architect, The Journal of AIA, Cladding plays an important role in creating fun and functional learning environments. Volume 105, number 8. August 2016. p:2-3.

Architect + design, an Indian journal of architecture, Clad in patterned glass. October 2016. p:60-69.

Brownell, Blaine, (2018), Concrete, It's electric! Architect. The journal of the American Institute of architects. Volume 107, number 10. October 2018. p:22.

Corner, Donald B., Jan C. Fillinger, and Alison G. Kwok, (2018). Passive house details. Solutions for high performance design. Routledge. Taylor \& Francis Group. New York.

Gobin, Christophe. (2019). Successful building using ecodesign. CRC Press. Taylor \& Francis Group. Boca Raton.

https://kbbi.kemdikbud.go.id/entri/atap, 10 Maret 2019, 17.20

https://kbbi.kemdikbud.go.id/entri/dinding, 10 Maret 2019, 17.25

https://kbbi.kemdikbud.go.id/entri/lantai. 10 Maret 2019, 17.30

Land, Karl Heinz. (2018). Earth 5.0. Provoke the future. Future Vision Press. Cologne.

Liauw, Franky. (2017). Arsitektur dalam keseharian, keseharian dalam arsitektur, Direktorat Penelitian dan Pengabdian kepada Masyarakat, Jakarta.

Razaz, Zeinab El, (2010), Sustainable vision of kinetic architecture, Journal of Building Appraisal, Vol. 4, 4, p:341-356.

Sullivan, Sue Anne, (2015), Realizing 21st century school design with Nanawall Flexspace, Architect. The Journal of the American Institute of Architects. Volume 104 number 1. January 2015. p:31.

Yudina, Anna (2015), Furniteture. Furniture that transforms space, Thames \& Hudson, New York. 